\title{
HasanuddinLawReview
}

\section{Indonesia's Archipelagic Sea Lanes (ASLs) Designation: Rights Turning to Obligations? ${ }^{1}$}

\section{Dhiana Puspitawati}

Law Faculty, Brawijaya University, Indonesia. E-mail: dhiana@ub.ac.id

\author{
ARTICLE INFO \\ Keywords: \\ Archipelagic State; \\ Navigational Rights; \\ Archipelagic Sea Lanes \\ Passage \\ How to cite: \\ Puspitawati, D. (2018). \\ Indonesia's Archipelagic Sea \\ Lanes (ASLs) Designation: \\ Rights Turning to \\ Obligations?. Hasanuddin \\ Law Review, 4(3): 265-280 \\ DOI: \\ 10.20956/halrev.v4i3.1488
}

\begin{abstract}
Indonesia is the first and only archipelagic state which has designated Archipelagic Sea Lanes (ASLs). However, such ASLs was only considered as a 'Partial ASLs' by the International Maritime Organization (IMO). This is due to the lack of the inclusion of all normal passage routes used for international navigation as required by Article 53 (4) of Law of the Sea Convention (LOSC). On the other hand, Indonesian national law stated that the rights of ASLP can only be exercised over the designated routes and this leave the undesignated routes under the innocent passage regimes, which is inconsistent with Article 53 (12) of LOSC. This article seeks to analyse Indonesia's rights in designating ASLs and the implementation of Indonesia's 'Partial ASLs'. It is questionable whether Indonesia's rights in designating ASLs has become an obligation by the 'partial' recognition of Indonesia's ASLs by IMO. While none reported incident of navigational rights over Indonesia's north-south ASLs, however some incidents did occur over the undesignated east/west ASLs. This paper begins with the analyses of the provisions of LOSC concerning archipelagic sea lines passage by looking at its travoux-preparatoir and then follows by the discussion of Indonesia's implementation on its designated ASLPs. Reported incident occurred over the undesignated ASLs will also be discussed to gain clear understanding on the matter. It is argued that Indonesia should either designated the east/west ASLs or if not, adjusting its national law to be in conformity with LOSC.
\end{abstract}

Copyright (C) 2018 HALREV. All rights reserved.

\section{Introduction}

As a leading proponent of an archipelagic state concept, Indonesia is very keen to implement all provisions relating to archipelagic state concept as provided within the LOSC. It is submitted that the implementation of an archipelagic state concept resulted in enclosing massive waters areas and the resources therein under the jurisdiction of an archipelagic state. Thus, it requires adequate efforts in balancing states' interest over the

1 Earlier version of this paper has been presented in AsianSIL Regional Conference on International Law and Dynamic Asia, Ha Noi, Vietnam, 14-15 June 2016 
ocean. This has been provided by the LOSC which represents its nature as a 'package deals' convention, within Part IV of LOSC. The 'package deals' in Part IV was drawn to balance the interests of archipelagic states and user maritime states, that is states which have main interests in accessing the ocean for their mobility. On the other hand, archipelagic states' interest is to preserve ocean resources for its people. The preservation of natural resources for the people of archipelagic state is clearly stated by Article 49 (1) and (2) of LOSC, which read:

(1) The sovereignty of an archipelagic State extends to the waters enclosed by the archipelagic baselines drawn in accordance with Article 47, described as archipelagic waters, regardless of their depth or distance from the coast.

(2) This sovereignty extends to the air space over the archipelagic waters, as well as to their bed and subsoil, and the resources contain therein.

Whereas the navigational rights of other states is accommodated within Article 53 of LOSC. Article 53 (1) of LOSC gives an archipelagic state the right to designate sea lanes and air routes there above to accommodate Archipelagic Sea Lanes Passage (ASLP) as envisages under Article 53 (2) and (3) of LOSC. Article 53 (4) further provides that if an archipelagic state choose to designate ASLs through its archipelagic waters, such ASLs should include all 'normal passage routes used for international navigation'. Following such provision, Article 53 (12) allows the rights of ASLP to be exercised through all 'normal passage routes used for international navigation', is the proposed ASLs by an archipelagic state does not include all 'normal passage routes used for international navigation' as envisages by Article 53 (4). Since the LOSC is silent on what constitute 'normal passage routes used for international navigation', it is argued that state interpretation and interests on such navigational rights remain debatable.

This article seeks to analyze Indonesia's rights in designating ASLs and the implementation of Indonesia's 'Partial ASLs'. It is questionable whether Indonesia's rights in designating ASLs has become an obligation by the 'partial' recognition of Indonesia's ASLs. While none reported navigational rights incident over Indonesia's north-south ASLs, however some incidents did occur over the undesignated east/west ASLs. It is argued that Indonesia should either designated the east/west ASLs or if not, adjusting its national law to be in conformity with LOSC.

\section{The Nature of Archipelagic State Concept}

One of the LOSC's unique features is the recognition of the archipelagic state principles. Although the concept of an archipelagic state had not been fully discussed until the commencement of UNCLOS III, in fact, the problem of archipelagos has been around far longer than might be surmised. The method of drawing baselines for the purpose of delimiting the territorial sea of archipelagos had been considered in many international meetings and conferences, namely: the Institute de Droit International meeting in 1888,2 the International Law Association in Stockholm in 1924, ${ }^{3}$ the American Institute of

2 Read further Natabaya, AS, (1978) “The Archipelagic Principles and Indonesia's Interests", Indonesian Quarterly 6 65, 66; Priestnall, Graham, (1997) “The Regime of Archipelagic Sea Lanes Passage and Straits Transit Passage" Maritime Studies 96, 1, 4.

3 Read further Coquia, Jorge R, (1983) "Development of the Archipelagic Doctrine as a Recognized Principle of International Law" Philippine Law Journal 58, 13 and Defensor, S, at al, (1974) "The Concept of Archipelago" Philippine Law Journal 49, 322. See also Dupuy, R \& Vignes, D, (1991) A Handbook of the New Law of the Sea, 270. 
International Law in 1925, ${ }^{4}$ the Harvard Research Draft on Territorial Waters in 19295 as well as in the Hague Codification Conference in 1930.6 However, none of the meetings came up with a solution for archipelagos.

The development of an archipelagic state concept cannot be disconnected from Indonesia's development on the law of the sea. ${ }^{7}$ In 1957 Indonesia had declared it selves to be archipelagic state through proclamation of 'Djuanda Declaration 1957', 8 which saw the integration of Indonesia's land and water territory under the exclusive sovereignty of the state. Unfortunately, the 'Djuanda Declaration 1957' was only a unilateral act by the Indonesian government and this underpinned the reason of UNCLOS I in rejecting the concept of an archipelagic state. Thus, in 1960 Indonesia produced UU 4/Prp/1960 on Indonesian Waters to formalized the concept within domestic formal legislation. However, during UNCLOS II the concept of archipelagic state was also rejected due to the lack of technical surveys. ${ }^{9}$

The next development was the Third Law of the Sea Conference (UNCLOS III), which lasted between 1974 and 1982. It was four leading archipelagic states, Indonesia, the Philippines, Mauritius and Fiji who had proposed a draft proposal on archipelagic principles in order to gain world-wide recognition of such principles. On March 14, 1973, the Chairman of the Philippines delegates Arturo Tolentino, on the behalf of those archipelagic states submitted to the Sea-Bed Committee four principles relating to archipelagic states, 10 as follows:

a. An archipelagic state, whose component islands and other natural features form an intrinsic geographical, economic and political entity, and historically may have been regarded as such, may draw straight baselines connecting the outermost points of the outermost islands and drying reefs of the archipelago from which the extent of the territorial sea of the archipelagic state is or may be determined.

b. The waters within the baselines, regardless of their depth or distance from the coast, the seabed and subsoil thereof, and the superjacent airspace, as well as all their resources, belong to and subject to the sovereignty of the archipelagic state.

c. The extent of territorial sea, economic and other jurisdictions of the state with regard to the sea around it shall be measured from these baselines; and

d. Innocent passage of foreign vessels through the waters of the archipelagic state shall be allowed in accordance with its national legislation, having regard to the

See American Journal of International Law (1926), special supplement, 318-9.

5 See American Journal of International Law (1929), special supplement to V.23, 260, 260-2; Journal of International Law (1929) 23, 275, 275.

6 See League of Nations, Document C.351 (b), M.145 (b) (1930) v. 16, 189; Amarasinghe, CF, (1974) “The Problem of Archipelagos in the International Law of the Sea" International and Comparative Law Quarterly 23, 545.

7 Since Dutch Colonialization, Indonesia's law of the sea was provided with the Territoriale zee Maritieme Kringen Ordonantie 1939, known as TZMKO 1939, within which it was provided that every islands of Indonesia has their own 3 nautical miles territorial sea. This arrangement resulted in the existing high seas between Indonesia's islands, making Indonesia's sea as separating factor rather than unifying factor. This, off course in contrary to the historical Indonesia's spirit in seeing the function of its surrounding ocean.

8 The Djuanda Declaration was declared on the $13^{\text {th }}$ of December 1957.

9 A/CONF.19/C.1/L.1, USSR: Proposal, dated 21 March 1960, UN Doc. A/CONF.19/C.1/L.5, Philippines: Amandments to Documents A/CONF.19/C.1/L.1 to L.4, dated 1 April 1960.

10 UN Doc. A/AC.138/SC.II/L.15, Archipelagic Principles as proposed by the delegations of Fiji, Indonesia, Mauritius and the Philippines: Explanatory Notes, dated 14 March 1973. 
existing rules of international law. Such passage shall be through sealanes as may be designated for the purpose by the archipelagic state.

From the above it is submitted that the reasons underpinned these principles were the unity of land, water and people into a single entity. As these came up, UNCLOS III finally adopted Law of the Sea Convention 1982 (LOSC), ${ }^{11}$ within which the concept of an archipelagic state was recognized as international law principles of archipelagic state. The essential features of the archipelagic state principle laid down by Part IV of LOSC include permission to draw straight archipelagic baselines around the outermost points of the outermost islands of archipelagos; and the recognition of the new and distinct concept of archipelagic waters for the waters thus enclosed of a nature designed to accommodate the interests of maritime user states, that are states which carry out certain activities, including navigation, in the water areas falling under the jurisdiction of archipelagic states.

Furthermore, it was argued that the definition of an archipelago state envisages in Article 46 (a) of LOSC 12 was intended to cover only those countries which are archipelagic states in the real sense and would exclude continental states which possess mid-oceanic archipelagos. In addition, the definition of an archipelago envisages in Article 46 (b) of LOSC ${ }^{13}$ shows that the legal concept of an archipelagic state is not limited to islands but includes part of islands. It requires the grouping to form an intrinsic geographical, economic and political entity, or to have been historically regarded as such. Thus, it is submitted that not every group of islands scattered on the sea would be an archipelago under this concept. In analysing the definition of archipelago provided within Article 46 (b) of LOSC four essential elements of archipelago can be identified as follows:

a. It is a group of islands including parts of islands and interconnecting waters and other natural features;

b. These islands should be closely inter-related;

c. They form an intrinsic geographical, economic and political entity; or

d. Are historically regarded as such.

Those elements raised multi-interpretations. How many islands are exactly can be called as 'a group of islands'? The 'closely inter-related' is also uncertain. While it might be argued to refer to the compactness nature of group of islands, it can be questioned as to how far the distance between the islands that meet the 'closely inter-related' requirement. The third and the forth elements are considered as the most satisfying elements. Thus, it is submitted that those four elements should be fulfilled in cumulative manner.

Furthermore, archipelagic states also have different arrangement as to the method of drawing their baselines, from which that various maritime zone measured. Such lines further function as the baselines of an archipelagic state from which the other maritime zones are measured. In drawing such baselines, Article 47 of LOSC sets out certain rules and conditions. ${ }^{14}$ As a result of drawing a distinct archipelagic baseline, a further question arose was on the status of waters enclosed by such baselines. While according to Article 8 (1) LOSC, waters enclosed by the straight baselines system of coastal

11 UN. Doc.A/CONF.62/ WP. 10/ Rev.3 and Add. 1 and Corr.1-6, Draft Convention, 1980.

12 See further Article 46 (a) of LOSC

13 See further Article 46 (b) of LOSC

14 See Article 47 of LOSC 
archipelagos are internal waters, it was questionable whether the waters enclosed by archipelagic baselines system should also be described as the same. ${ }^{15}$ As this turn out, LOSC termed the waters enclosed by archipelagic baselines as archipelagic waters, over which the sovereignty of archipelagic states is extended with the exception of existing navigational rights.

\section{Navigational Rights over Archipelagic Waters}

As mentioned earlier, the drawing of archipelagic baselines would result in the question of whether navigational rights over the enclosed sea are still be preserved? Under Article 5 (1) CTSCZ 1958 and Article 8 (1) LOSC, waters enclosed by the straight baselines system of coastal archipelagos are internal waters, over which no passage of foreign ships are allowed. If the waters enclosed by archipelagic baselines are considered the same as internal waters and thus no passage of foreign ships are allowed, this would raise major objections from other states, especially user maritime states. As this turn out, LOSC provides new regime known as archipelagic waters.

Article 49 of LOSC provides that the sovereignty of an archipelagic state is extended over waters enclosed by archipelagic baselines, known as archipelagic waters. However, it then raised the question of the extent of that sovereignty. Archipelagic waters are located between the islands of an archipelago and the landward side of archipelagic baselines. So, basically, the sovereignty of an archipelagic state over its archipelagic waters should be similar to but not identical to that over land territory. In formulating LOSC, the reciprocity principle was used in the debates and negotiations. ${ }^{16}$ In return for the acknowledgement of its sovereignty over the extended ocean areas, archipelagic states recognized the right of passage of user maritime states through their waters as long as the passage did not undermine the sovereignty of the archipelagic state. The problem was whether the juridical status of archipelagic waters is more closely related to internal waters or territorial sea. While the archipelagic states argued that the juridical status of archipelagic waters is closely related to internal waters, and that the only applicable regimes of passage is innocent passage, user maritime states saw this more closely to territorial waters. This is because no innocent passage exists in internal waters. If archipelagic states were aimed to accommodate the interests of user maritime states by allowing the exercised of innocent passage, thus archipelagic waters were closely related to territorial sea.

The drawing of archipelagic baselines, especially by Indonesia requires distinct navigational regimes. Not only is the area which comprises Indonesia's archipelagic waters the largest of all properly constituted archipelagic states, 17 but the inclusion within those waters of vital international straits such as Lombok and Sunda renders the area the most important to the international navigation. Based on the above considerations, the international community was prepared to recognize the concept of an archipelagic state only on the condition that crucial navigational rights would be specifically preserved in the text of the LOSC. This juridical quid pro quo ${ }^{18}$ built the

15 Symmons, Clive R, (1978), The Maritime Zones of Islands in International Law, 68.

16 Interview with Prof. Dr. Hasjim Djalal, MA, former Indonesian Ambassador to UN, Canada, Germany and Ambassador at large for the Law of the Sea, also Head of Indonesian Representative on the designation of Indonesian ASLs to the IMO (Jakarta, 27 October 2003).

17 See table 1 of this thesis.

18 This leads to the 'package deals' nature of LOSC and refers to the existence of the 'reciprocal deals' emerging from the vast number of conflicting interests. See Agoes, Etty R, "The Law of the Sea and 
fundamental nature of the negotiations and as this turn out, the LOSC recognises two navigational rights over the archipelagic waters, namely the right of innocent passage, which can be exercised through archipelagic waters other than the designated sea lanes ${ }^{19}$ and the "new" navigational rights over such waters - archipelagic sea lanes passage (ASLP).

\subsection{Archipelagic Sea Lanes Passage: International and National Legal Perspectives}

The regime of ASLP evolved as an attempt to balance the territorial integrity and national security of archipelagic states with the right of passage through waters enclosed the archipelagic baselines. However, such regimes raised different perspectives internationally and nationally. The crucial provisions which raised different perspectives involves Article 53 (3), (4) and (12). The definition of ASLP as envisages in Article 53 (3) of LOSC consists of at least three elements, namely: (i) it provides the rights of navigation and overflight; (ii) the passage should be exercised in normal modes; and (iii) the passage should be continuous, expeditious and unobstructed transit between one part of the high seas or an exclusive economic zone, and another part of the high seas or an exclusive economic zone. This definition is derives from, the definition of transit passage. The similarities between archipelagic sea lanes passage and transit passage are commonly cited by maritime powers and user maritime states to justify a more liberal perspective on navigation through archipelagic waters. ${ }^{20}$

In relation to point (i), the difference is that archipelagic sea lanes passage provides 'the rights of navigation' 21 , whereas transit passage is 'freedom of navigation'.22 The term 'rights of navigation' is appropriate with respect to Article 49 of LOSC, which extends archipelagic states' sovereignty to waters enclosed by archipelagic baselines drawn in accordance with Article 47 of LOSC. In the light of the above, it is argued that the difference between 'freedom' and 'rights' lies in the degree of obedience to certain rules. Similarly, Djalal writes, "[t]he exercise of a right implies certain obedience to specific rules, while the exercise of freedom may be less so." 23 Another difference, identified by Batongbacal, is that archipelagic sea lanes passage can be exercised over all archipelagic waters or waters inside the archipelagic baselines, wherever the sea lanes are located, designated and established. Transit passage, however, is only available to foreign ships in straits used for international navigation, and not in national or domestic straits that are entirely within the archipelagic baselines. ${ }^{24}$

In relation to point (ii) of the elements of ASLP, the words 'normal modes' 25 requirement of archipelagic sea lanes passage leads to another problem as LOSC does not specify the meaning of normal modes, especially for submarines. The words 'normal modes', could lead to a different interpretation from different parties. Reisman makes the point that

Navigation: The Indonesian Archipelagic State Perspective" in Rothwell, Donald R and Bateman, Sam (eds), (2000), Navigational Rights and Freedoms and the New Law of the Sea, 144, 146.

19 Article 52 of LOSC.

20 Batongbacal, Jay L, (2002) “A Philippine Perspective on Archipelagic State Issues" Maritime Studies 122, 1,28

21 Article 53 (3) of LOSC.

22 Article 38 (2) of LOSC.

23 Djalal, Hasjim, "The 1982 U.N. Convention on the Law of the Sea and Navigational Regimes" in Johnston, Douglas M and Sirivivatnanon, Ankana, (2002) Maritime Transit and Port State Control: Trends in System Compliance, 74, 79 .

24 Batongbacal. (2002) above n 20.

25 Article 53 (3) of LOSC. 
maritime user states could argue for what is 'normal' will depends on context, including the legal environment. ${ }^{26}$ Furthermore, Moore suggests, in interpreting such a provision and applying it to submarines, one should consider the negotiating text which underpins the formulation. In his view, "...recourse may be had to the negotiating context, which I believe makes abundantly clear that this phrase includes submerged transit." 27 Agoes, 28 referring to Article 39 (1) of LOSC, 29 argues that if submarines are allowed to make submerged passage while undertaking transit passage, the sovereignty of coastal states might be diminished. This is because it would be difficult for coastal states, which are mostly developing states with inadequate marine technology, to monitor submarines making submerged passage. However, as Moore points out, such a provision does not necessarily give a coastal state the right to require a submarine to navigate on the surface while undergoing transit passage. ${ }^{30}$

Similarly, Jayawardene argued that under Article 53 there is no reference to submarines to navigate on the surface as is the case in the territorial sea, so 'normal modes' implies submerged passage for submarines. ${ }^{31}$ It is submitted that the definition of 'normal modes' signifies that the ship could navigate in its 'own normal mode' which refers to the safety for passage of that particular type of ship. For submarines to safely navigate submerged often require a depth of $50 \mathrm{~m}$ or more. ${ }^{32}$ Consequently, if the depth of the sea is less than $50 \mathrm{~m}$ (as is the depth of the Java Sea along the east/west routes of the Indonesian archipelago), then, the submarine may well navigate on the surface for the sake of its safety. ${ }^{33}$ Thus 'normal modes' may mean submerged or on the surface as dictated by the ship's safety. For example, a diesel submarine must periodically surface to recharge its batteries or to replenish its air supply, then its normal mode comprises both modes, surface and submerged. This goes the same for hovercraft, which needs the foilborne or airborne navigation for its safety. For an aircraft, the normal mode would include the flight at normal speed and altitude. While the LOSC is silent on the criterion of 'normal modes', the right of submarines to pass submerged through archipelagic sea lanes is considered by some as the biggest 'give away' by the archipelagic states at UNCLOS III. 34

Besides the submerged passage of submarines as the meaning of 'normal mode' for ships traversing archipelagic waters under the regime of ASLP, the 'normal mode' also can be referred to the specific modes of passage of other military ships, such as the need for an aircraft carrier and its protecting vessels to move in formation protecting air and surface assets. ${ }^{35}$ It is argued that 'normal modes' permit an as yet undetermined range of

26 Reisman, Michael W, (1980), "The Regime of Straits and National Security: An Appraisal of International Law Making" American Journal of International Law 74, 48, 76.

27 Moore, John Norton, (1980), "The Regime of Straits and the Third United Nation Conference on the Law of the Sea" American Journal of International Law 74, 77, 121.

28 Agoes, Etty R, (1991), Konvensi Hukum Laut 1982: Masalah Pengaturan Hak Lintas Kapal Asing, 136.

29 Article 39 (1) of LOSC reads "refrain from any threat or use of force against the sovereignty, territorial integrity or political independence of States bordering the straits, or in any other manner in violation of the principles of International Law embodied in the Charter of the United Nations.

30 Moore (1980) above n 272727.

31 Jayawardene, Hiran, W, (1990), The Regime of Islands in International Law (1990), 162.

32 Email from CDR Iwan Isnurwanto, Captain of KRI. Cakra-401, Indonesian Submarine to the author, 5 August 2005.

33 Ibid.

34 See Narokobi, Camillus, S.N., "The Regime of Archipelagos in International Law" in Van Dyke, J.M., Alexander, L.M., and Morgan, J.R. (eds) (1988) International Navigations: Rocks and Shoals Ahead?, 232.

35 Alexander, Lewis M, (1986), Navigational Restrictions within the New Law of the Sea Context: Geographical Implications for the United States, 38. For similar point of view that 'normal mode' would enable an aircraft carrier and its protecting vessels to move in formation, see further Johnson, Constance, (2000) "A Rite of 
activities for military vessels transiting, maintenance of ship formations, continuous operation of naval surveillance and monitoring equipment, constant weapons-readiness status, and launch and recovery of aircraft, which are not permitted in the case of innocent passage through the territorial water. ${ }^{36}$

From the above arguments, it is evident that there are gaps within the provisions concerning 'normal modes', which can be a disadvantage to coastal states and maritime user states and bring both interests into conflict. If the provisions are interpreted as giving rights for submarines to travel submerged, then it can be seen as a challenge to coastal states' sovereignty. On the other hand, user maritime states would object to an interpretation that the provisions implicitly oblige submarines to navigate on the surface.

In relation to point (iii) of the definition of ASLP, there were most significant negotiating text change from 'solely for the purpose of continuous and expeditious transit' to 'solely for the purpose of continuous, expeditious and unobstructed transit.' Whilst the earlier repeated the definitions of the innocent passage and transit passage, the later adds the word 'unobstructed'. This appears to increase the extent of the navigational right, although, since 'unobstructed' was not defined, its actual effect is not quantifiable. Nevertheless, Djalal ${ }^{37}$ pointed out that there is a difference between the words 'unobstructed' and 'shall not be impeded' in transit passage. Although their meanings are not clear-cut, he argued that the use of different terminology would signify different situations. However, this is debatable since Djalal seemed to justify the difference of those two terms relating to the location over which the right of ASLP and transit passage apply. In the circumstance where straits are located within archipelagic waters and are designated as ASL(s), the differences of the two terms do not matter. Thus, it is submitted that the difference between the meanings of 'unobstructed' and 'shall not be impeded' is questionable.

Furthermore, Wisnumoerti 38 argued that the word 'unobstructed' would defeat the word 'right'. While the word 'right' reflects certain obedience to specific rules, the word 'unobstructed' passage would, in fact, limit the sovereignty of archipelagic states. ${ }^{39}$ The word 'unobstructed' was proposed by Indonesia. ${ }^{40}$ Therefore, similarly, Bernhardt questioned "why Indonesia would introduce a word which by its plain meaning is inimical to its own interests and evidently favours navigation is inexplicable and not surprisingly, no maritime power objected to its inclusion." 41 This proposal was inconsistent with Indonesia's previous position, which argued for the right of innocent passage over archipelagic waters. ${ }^{42}$ However, it should be borne in mind that ASLs are defined as a series of continuous axis lines from the entry points of passage routes to the

Passage: The IMO Consideration of the Indonesian Archipelagic Sea-Lanes Submission” The International Journal of Marine and Coastal Law 15, 317.

36 See Batongbacal, J, (1997) “The Philippines' Right to Designate Sea Lanes in its Archipelagic waters Under International Law" Ocean Law and Policy 1, 81. See also Warner, Robin, (1997) "Defence Related Aspects of the Archipelagic Sea Lanes Regime" Proceeding of Annual Conference of Australia and New Zealand Society of International Law 5, 163, 168.

37 Djalal (2002) above n 23, 77.

38 Wisnumoerti, Nugroho, (1988) “Archipelagic waters and Achipelagic Sea Lanes” in J. Van Dyke, L. Alexander and J.Morgan (eds), International Navigation: Rocks and Shoals Ahead? 198, 205.

39 Ibid.

40 Article 53 of ICNT.

41 Bernhardt, Peter J, (1995) “The Right of Archipelagic Sea Lanes Passage: A Premier” Virginia Journal of International Law 35, 719, 738.

42 Ibid. 
exit points. ${ }^{43}$ Thus, Mengko has argued that ASLs are not corridors but merely an access to archipelagic waters. ${ }^{44}$ As soon as foreign vessels pass through archipelagic waters, the waters left behind are closed and are under Indonesian jurisdiction. 45 This way, the word 'unobstructed' does not have any effect in limiting an archipelagic states' sovereignty. In sum, Article 53 (3) is the functional equivalent of the transit passage regime with the exception of the word 'unobstructed' which arguably gives an edge to the transiting state.

Moving now on the discussion on where the right of ASLP can be exercised. According to Article 53 (1) of the LOSC, an archipelagic state may designate sea lanes through and air routes over its archipelagic waters and territorial sea. 46 Such sea lanes and air routes must include all normal passage routes and navigational channels used as routes for international navigation, except that duplication of routes of similar convenience between the same entry and exit points are not necessary. 47 If it fails to do so, the right of ASLP may be exercised through the routes normally used for international navigation. ${ }^{48}$ Indonesia is the first and the only archipelagic state ever designate its ASLs. The Indonesian ASLs proposal submitted to the IMO was ultimately adopted, lanes run between: (i) the South China Sea and the Indian Ocean. The lane has two northern ends both commencing in the South China Sea between (Peninsular) Malaysia and Kalimantan and proceeds through the Sunda Shelf area (between Sumatra and Kalimantan and the western end of the Sunda Islands) to the Indian Ocean via the Sunda Strait (between Sumatra and Java); (ii) the Celebes Sea and Indian Ocean. The lane's northern end commences in the Celebes Sea and proceeds through the Makassar Strait (between Kalimantan and Sulawesi), the Java Sea and into the Indian Ocean (via the Lombok Strait); and (iii) the Pacific Ocean and Indian Ocean, Timor Sea or Arafura Sea. The lane has two northern ends both commencing in the Molucca Sea and proceeds through the Moluccas and the Abndu Sea. The lanes have three southern ends which proceed (a) along the south-west coast of Timor into the Sawu Sea and the Indian Ocean; (b) past the eastern tip of Timor Leste and into the Timor Sea; and (c) to the Arafura Sea. ${ }^{49}$ Such ASLs can be illustrated as follows:

43 Article 53 (5) of LOSC.

44 Mengko, Jost (Laksda (purn), “ALKI bukan koridor tapi akses” Sinar Harapan (Jakarta) 12 Juli 2003.

45 Ibid.

46 Article 53 (1) of LOSC.

47 Article 53 (4) of UNCLOS.

48 Article 53 (12) of LOSC.

49 Ibid. 


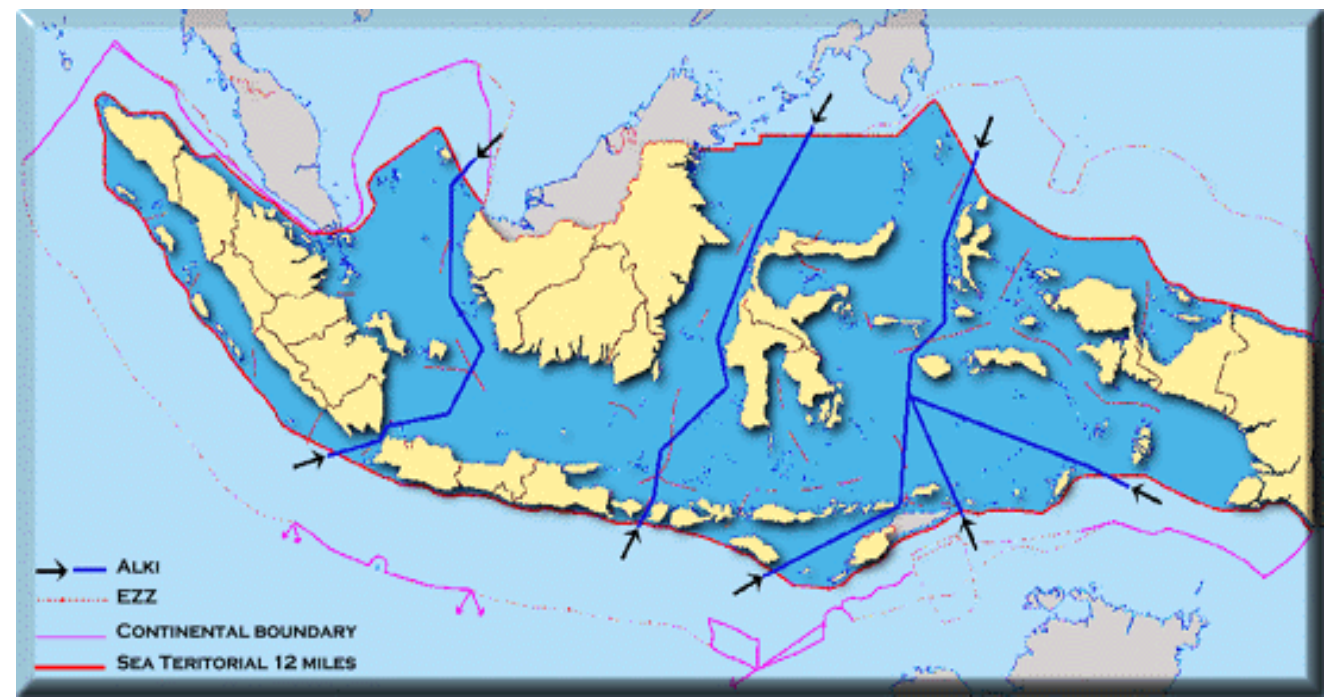

Figure 1. Indonesia's Archipelagic Sea Lanes (Blue Lines)

Although it seems Indonesia has established its ASLs to accommodate the rights of ASLP through Indonesia's archipelagic waters, such designated ASLs raised tension between archipelagic states and user maritime states both regionally and internationally, with regard to interpretation of Article 53 (3), (4) and (12) of the LOSC. The following discussions analyses such tension.

\subsection{Regional and International Tension on Navigational Rights over Indonesian Waters}

Indonesia's efforts in designating ASLs went through series of consultations domestically ${ }^{50}$ as well as internationally with user maritime states. ${ }^{51}$ While Indonesia only designated three north/south ASLs and did not designate ASL(s) running through the east/west route, both Australia and the USA suggested that Indonesia should add ASL(s) running through the east/west routes. In addition to this, Australia suggested Indonesia add another north/south ASL running from the Arafura Sea to the Pacific Ocean through the deeper waters between Maluku and Irian Jaya. Despite of such suggestions, Indonesia did go ahead to the $\mathrm{IMO}^{52}$ with only three north/south ASLs.

50 The Indonesian three north/south ASLs were approved domestically by a National Working Group Meeting held in Cisarua, Bogor on 17-19 January 1995. See Ello, Nicolas P, "Hasil Sidang IMO dan Konsultasi IHO tentang ALKI dalam rangka implementasi UNCLOS 1982", (Laporan pada MabesAL, Dishidros AL, Jakarta, September 1997), 1. While it was recognized in this meeting that the proposed ASLs produced during the Indonesian Navy Strategic Forum in 1991 was incomplete owing to the absence of the east/west ASL(s), the meeting also noted that under LOSC the designation of ASLs is not an obligation and therefore the designation of the three north/south ASLs did not automatically close the possibility of further ASLs designation covering all normal passage routes used for international navigation. Thus, in this meeting the three north/south ASLs were formally agreed. It was also made clear in the meeting that the reason for the absence of the east/west ASL(s) was because Indonesia has not conducted any studies and surveys through the Java Sea. See Kustia, AA (Rear Admiral), "Hasil evaluasi Panja TNI-AL tentang Penentuan Alur Laut Kepulauan Indonesia", (Speech delivered at Laporan Hasil Evaluasi ALKI di MabesAL, Jakarta, 1996), 1-8. Also Interview with Anas Siradju, SH, MH, Captain (Retd), the former Head of Indonesian Navy Legal Division, Eastern Fleet, who involved closely during the preparation of the ASLs designation (Surabaya, 26 August 2003).

51 While Japan and The United Kingdom did not raise significant objections, on the other hand, the USA and Australia raised crucial objections relating to the absence of the east/west ASL(s).

52 This is in accordance with Article 53 (9) which refers to competent international organization in approving designated ASLs designated by archipelagic states. While Agoes questioned the competence 
As this turns out, the 69 th session in May 1998, of the Maritime Safety Committee (MSC) adopted the General Provisions for the Adoption, Designation and Substitution of Archipelagic Sea Lanes (GPASL) ${ }^{53}$ approving Indonesia's ASLs proposal. The GPASL emphasizes and enlarges what was already provided under LOSC. 54 While it is believed that the GPASL clarified LOSC's provisions pertaining to the right of ASLP, 55 the GPASL considered Indonesia's ASLs proposal as the 'partial ASLs proposal', which was not envisaged in the LOSC. This 'partial ASLs proposal' is defined by the GPASL as "a proposal which does not meet the requirement to include all normal passage routes and navigational channels as required by LOSC." 56 Accordingly, the GPASL further reinforced the obligation upon archipelagic state to complete and include all normal passage routes used for international navigation in its proposal. It is argued that under this concept of 'partial ASLs proposal', approval of the three north/south Indonesian ASLs did not prevent the continued exercise of ASLP in other routes normally used for international navigation located within the archipelagic waters. ${ }^{57}$ At this point, it is questionable whether the designation rights's of Indonesia become obligation upon the 'partial' recognition by IMO?

Batongbacal argued that the concept of 'partial ASLs proposal' can be critically questioned. He submitted that since such a concept does not prevent the exercise of the ASLP in undesignated routes, it leaves the designation meaningless. ${ }^{58}$ In addition, he stated that the concept of partial designation "nullifies the benefit of designating any ASLs at all." 59 With reference to Article 53 (4) and (12) of LOSC he further argued that the partial designation of ASLs would make these ASLs ineffective:

No benefit is gained by the archipelagic state in making a partial proposal and designations, since all routes not designated are still subject to ASLP anyway. A partial designation is like no designation at all.60

of IMO as competent international organization, international community agrees to refer to IMO for approving proposed ASLs of archipelagic states. See Agoes, Etty R, "International Maritime Organization (IMO) dan Peranannya dalam Penetapan alur-alur Laut Kepulauan Indonesia (ALKI)" in Komar, Mieke, Agoes, Etty R and Damian, Eddy (eds), (1999) Mochtar Kusumaatmadja: Pendidik dan Negarawan, Kumpulan Karya Tulis Menghormati 70 Tahun Prof. dr. Mochtar Kusumaatmadja, SH, LLM 568, 570. Similarly, the competence of the ICAO with regard to Article 54 of LOSC 1982 was also doubted.

53 IMO Doc. MSC 69/22/Add.1, General Provisions for the Adoption, Designation and Substitution of Archipelagic Sea Lanes (GPASL), dated 19 May 1998.

54 The GPASL, inter alia, clarify the procedures and function of the IMO relating to ASLs proposals; the responsibilities of an archipelagic state submitting a proposal; the criteria for considering and adopting proposals; further details on the use of ASLs and normal passage routes; and technical requirements for defining ASLs. In the GPASL more arduous pre-proposal procedures especially for the archipelagic state; and a formalized role for foreign states in relation to the preparation and determination of a proposal were regulated.

55 GPASL para. 2-7.

56 GPASL para. 2.2.2

57 GPASL para. 6.7. On Indonesia's response to the IMO designation, see Ministry of Foreign affairs of the Republic of Indonesia, “On Indonesia's Archipelagic Sealanes” (Press Release No. 28/PR/VI/98, 15 June 1998) <www.deplu.go.id/english2/pr28-98.htm> at 27 March 2004. For similar point of view see also Djalal, Hasjim, "The 1982 UN Convention on the Law of the Sea and Navigational Regimes" in Johnston, D.M. and Sirivivatnanon, A (eds) Maritime Transit and Port State Control: Trends in System Compliance (2000) 74, 79-80.

58 Batongbacal, Jay, (2004) “Barely Skimming the Surface: Archipelagic Sea Lanes Navigation and the IMO" in Elfrink, A.G. Oude and Rothwell, Donald R (eds), Oceans Management in the 21st Century: Institutional Framewok and Responses 49, 67.

59 Ibid.

$60 \quad$ Ibid, 55. 
While Batongbacal argument might be true, however, for Indonesia that is not necessarily the case. In Indonesia, it is argued that the normal passage routes used for international navigation include the north/south as well as east/west navigational routes. Although the Indonesia's north/south ASLs are deemed as 'partial ASLs proposal', the designation of these ASLs in fact has benefited Indonesia. While there are many versions of north/south navigational routes, the existence of the designated north/south ASLs would make all foreign ships navigate strictly through the designated north/south ASLs under the regime of ASLP. This would make the monitoring of the passage of foreign ships in order to assist the voyages of foreign ships traversing the archipelagic waters, become easier for Indonesia. This way, it is submitted that the designation of north/south ASLs was not necessarily meaningless. In addition, while over the east/west routes the right of ASLP can be exercised through all normal passage routes used for international navigation (due to the absence of the designated east/west ASLs), this condition does not affect the existence of the designated north/south ASLs.

Batongbacal further believed that the GPASL might undermine the LOSC. ${ }^{61}$ However, it is argued that what the GPASL did was only emphasizing what had been regulated by LOSC, which related to Article 53 (4) and (12). Thus, it is further questionable whether the provisions of LOSC specifically Article 53 (4) and (12) in fact favour the interest of user maritime states than archipelagic states'. Bernhardt, addressing the wording of Article 53 of LOSC, stated:

"[W]hy Indonesia would introduce a word which by its plain meaning is inimical to its own interests and evidently favours navigation is inexplicable and not surprisingly, no maritime power objected to its inclusion." 62

Despite the controversy over the term 'partial ASLs proposal', it was the Indonesian position to recognize the exercise of the right of ASLP through the east/west, as stated:

"Pending the designation of other sea lanes through other parts of the archipelagic waters, the right of archipelagic sea lanes passage may be exercised in the relevant archipelagic waters in accordance with the Law of the Sea Convention 1982."63

Similarly, GPASL also provided that:

"Where a partial archipelagic sea lanes proposal has come into effect, the right of archipelagic sea lanes passage may continue to be exercised through all normal passage routes used as routes for international navigation or overflight in other parts of archipelagic waters in accordance with UNCLOS."64

In sum, Indonesia seems to approve the fact that its proposed ASLs is considered as 'partial ASLs' and with regard to east/west routes, which was demanded as complete normal passage routes used for international navigation, it was Indonesia's position that foreign ships may exercise ASLP through east/west routes which was considered as routes used for international navigation.

$61 \mathrm{Ibid}$.

62 Bernhardt, JPA, “The Right of ASLP: A Premier” (1995) 35 Virginia Journal of International Law 719, 743.

63 IMO Doc. MSC 67/7/2, para. 11.

64 GPASL para. 6.7. 


\section{The Practice of Indonesia: Remaining Problems and Obstacles}

After IMO's approval on Indonesia's proposed ASLs, Indonesia enacted Indonesian Government Regulation No. 37 Year 2002 (herein after called Regulation 27/ 2002) on the Rights and Obligations of Foreign Ships and Aircraft Exercising the Right of Archipelagic Sea Lanes Passage through Designated Archipelagic Sea Lanes. While it was clearly stated in IMO Document MSC 67/7/2 paragraph 11 and paragraph 6.7 of the GPASL that pending the designation of other sea lanes through other parts of archipelagic waters, in this case refer to the east/west routes, the ASLP regimes still can be exercised in such routes, Regulation 37/ 2002 suggests different arrangement. Article 3 of Indonesian Government Regulation 37/ 2002 (hereinafter, Regulation 37/2002) which reads as follows:

(1) The exercise of the right of archipelagic sea lanes passage as described in Article 2 is conducted through a sea lane or air route above the sea lane designated as an archipelagic sea lane for the purpose of transit in such sea lanes, as stipulated in article 11.

(2) Pursuant to this regulation, to exercise the right of archipelagic sea lane passage in other parts of Indonesian waters can be conducted after such sea lane has been designated in those waters for the purpose of this transit. 65 (Italics added)

Further, Article 15 of Regulation 37/2002 provides that:

Six months after this government regulation was enforced, foreign ships and aircraft can exercise the right of archipelagic sea lanes passage only through the designated Indonesian archipelagic sea lanes as stipulated in this government regulation.66 (Italics added)

While it is acknowledged that innocent passage is applicable in other parts of archipelagic waters other than the designated ASLs, 67 it is unclear whether Article 3 and 15 of the Regulation 37/2002 recognized the exercise of ASLP in all normal passage routes used for international navigation in the absence of the designated sea lanes. The elucidation paragraph of the Regulation 37/2002 emphasized this by recognizing the passage of foreign ships through the undesignated routes would be limited to innocent passage 68 and that the right of ASLP is applicable only through the three north/south ASLs. ${ }^{69}$ In contrast, as discussed in the previous sections that according to Article 53 (4) and (12) as well as paragraph 6.7 of the GPASL and paragraph 11 of the IMO Doc. MSC $67 / 7 / 2$ relating to the note of Indonesia, in the absence of the designated ASLs, the right

65 Article 3 of the Indonesian Government Regulation 37/2002, in IMO Doc. SN/Circ. 200/Add.1, Adoption, Designation and Substitution of Archipelagic Sea Lanes, dated 3 July 2003.

66 Article 15 of the Regulation 37/2002.

67 In the existence of the designated ASLs, the right of ASLP only operates in such designated ASLs. Elsewhere in archipelagic waters (except in internal waters, over which the passage of foreign ships is prohibited), ships, but not aircraft, of all states enjoy the right of innocent passage. Therefore, two regimes of passage opearate in archipelagis waters, namely: innocent passage and ASLP. The rights of ASLP can be exercised in the designated ASLs, and in such case, the innocent passage regimes applicable in other part of archipelagic waters other than the designated ASLs. However, in the absence of the designated ASLs the rights of ASLP can be esxercised through all normal passage routes used for international navigation. See generally Article 53 of LOSC and specifically Article 53 (4) and (12) of LOSC.

68 Paragraph 11 of the Elucidation of Regulation 37/2002, Additional State Gazette (2002) No. 4210.

69 Indonesian Navy in field consider that owing to the absence of the east/west ASLs, only the right of innocent passage is allowed over the east/west routes. Interview with CDR Iwan Isnurwanto, Captain of KRI Cakra-401, Indonesian Submarine (Surabaya, 24 August 2006). 
of ASLP can be exercise through all normal passage routes used for international navigation, in this regard, the east/west routes. The remaining problem is when a foreign ship traversing archipelagic waters through east/west route, will that ship exercise ASLP or innocent passage due to the absence of designated ASLs over such routes?

The above discussion suggested a potential conflict between municipal law and international law as to which law should prevail. Municipal law governs the domestic aspects of government and deals with issues between individuals, and between individuals and the administrative apparatus, while international law focuses primarily upon the relations between states..$^{70}$ While theoretically, there are three approaches in seeing the relationship between international and municipal law, ${ }^{71}$ however, the general rule with regard to the position of municipal law within the international sphere is that a state which has broken a stipulation of international law cannot justify itself by referring to its domestic legal situation..$^{72}$ It is no defence to a breach of an international obligation to argue that the state acted in such a manner because it was following the dictates of its own municipal laws. Thus, it is submitted that the Regulation 37/2002 alone cannot be used to justify the prohibition of the right of ASLP over the east/west routes. It is further submitted that Indonesia cannot simply ask foreign ships navigating through the east/west routes to navigate under the right of innocent passage as dictated by Indonesia's municipal law.

\section{Conclusions}

The LOSC's nature of package deal which was formulated based on a quid pro quo basis aimed at balancing states' interest on the use of the ocean. However, such arrangement resulted in a multi-interpretation on related provisions which lead to inconformity between national law and international law. Such arrangement also raised tension between archipelagic state and user maritime states. LOSC's provisions on archipelagic state, consequently required an archipelagic state to designate ASLs to accommodate other states' navigational rights through archipelagic waters.

70 See generally Kusumaatmadja, Mochtar, (1997) Pengantar Hukum Internasional I dan II ; Starke, J.G., (1999) Introduction to International Law (10th Ed); Brownlie, Ian, Principles of Public International Law (6 $6^{\text {th }}$ Ed, 2003); Malanczuk, Peter, Akerhurst's Modern Introduction to International Law (7th Ed, 1997); Shaw, Malcolm N, International Law (4th Ed, 1997); Shearer, I.A., Strake's International Law (11th Ed, 1994).

71 Ibid. The first approach, known as dualism or pluralism stresses that the rules of the system of international and municipal law exist separately and thus, cannot purport to have an effect on, or overrule the other. The second approach is known as monist, which upholds a unitary view of laws as a whole and is opposed to the strict division posited by the dualism theory. It supported the supremacy of international law over the municipal law. The third approach, being somewhat a modification of the dualist position, among other things, attempts to establish a recognized theoretical framework tied to reality. This approach begins by denying that any common field of operation exists as between international law and municipal law by which one system is superior or inferior to the other. International law and municipal law are two legal systems each operating within its own field and exist within different juridical orders.

72 Article 27 of the Vienna Convention on the Law of Treaties 1969 (1980 UKTS 58) relating to internal law and observance of treaties, states that: "A party may not invoke the provisions of its internal law as justification for its failure to perfom a treaty." This rule is without prejudice to Article 46 of the same Convention, which states: "A State may not invoke the fact that its consent to be bound by a treaty has been expressed in violation of a provision of its internal law regarding competence to conclude treaties as invalidating its consent unless that violation was manifest and concerned a rule of its internal law of fundamental importance and a violation is manifest if it would be objectively evident to any state conducting itself in the matter in accordance with normal practice and in good faith." 
It is submitted that the requirements of Article 53 paragraph (4) ${ }^{73}$ and (12) of the LOSC may defeat the purpose of establishing the ASLs in the first place under subsection (1) as the designated ASLs would be identical to the routes used for international navigation. ${ }^{74}$ If a complete ASL designation must at all times include 'all normal passage routes', then there is no situation in which substitution can be called for, nor is there any opportunity to eliminate redundant routes; for that matter, neither is there any more utility in designating any ASLs since ASLP can be exercised practically anywhere in archipelagic waters. In addition to this, the undefined "routes normally used for international navigation' also raised problem, especially in its implementation. While it is debatable whether the change of LOSC's provisions on archipelagic state concept is necessary, it is also questionable whether the quid pro quo arrangement has been achieved? In case of Indonesia, it is submitted that Indonesia has done its best to implement the archipelagic state's provisions according to LOSC. However, when it came to national law, somehow the interpretation and priority has changed. It is questionable whether Indonesia's right in designating ASLs has become an obligation by the 'partial' recognition of Indonesia's ASLs. By the virtue of 'partial ASLs' envisaged in the GPASL, it is submitted that Indonesia should either designated the east/west ASLs or if not, adjusting its national law, in this case the Regulation 37/2002, to be in conformity with LOSC. Thus, recognising the rights of archipelagic sea lanes passage through the east/west routes for foreign vessel.

\section{References}

Amarasinghe, CF, (1974) "The Problem of Archipelagos in the International Law of the Sea" International and Comparative Law Quarterly 23, 545.

Batongbacal, J, (1997) “The Philippines' Right to Designate Sea Lanes in its Archipelagic waters Under International Law" Ocean Law and Policy 1, 81.

Batongbacal, Jay L, (2002). “A Philippine Perspective on Archipelagic State Issues" Maritime Studies 122, 1, 28

Bernhardt, JPA, “The Right of ASLP: A Premier” (1995) 35 Virginia Journal of International Law 719, 743.

Bernhardt, Peter J, (1995) "The Right of Archipelagic Sea Lanes Passage: A Premier" Virginia Journal of International Law 35, 719, 738.

Coquia, Jorge R, (1983) "Development of the Archipelagic Doctrine as a Recognized Principle of International Law" Philippine Law Journal 58, 13.

Defensor, S, et al, (1974) “The Concept of Archipelago" Philippine Law Journal 49, 322. See also Dupuy, R \& Vignes, D, (1991) A Handbook of the New Law of the Sea, 270.

Elfrink, A.G. Oude and Rothwell, Donald R (eds), Oceans Management in the 21 ${ }^{\text {st }}$ Century: Institutional Framewok and Responses 49, 67.

J. Van Dyke, L. Alexander and J.Morgan (eds), International Navigation: Rocks and Shoals Ahead? 198, 205.

33 Article 53 (4) of LOSC.

74 Djalal, Hasjim, (2000) "The Law of the Sea Convention and Navigational Freedoms" in Rothwell, Donald $\mathrm{R}$ and Bateman, Sam (eds), Navigational Rights and Freedoms and the New Law of the Sea 1, 6-7. 
Johnson, Constance, (2000) "A Rite of Passage: The IMO Consideration of the Indonesian Archipelagic Sea-Lanes Submission" The International Journal of Marine and Coastal Law 15, 317.

Johnston, D.M. and Sirivivatnanon, A (eds) Maritime Transit and Port State Control: Trends in System Compliance (2000) 74, 79-80.

Johnston, Douglas M and Sirivivatnanon, Ankana, (2002) Maritime Transit and Port State Control: Trends in System Compliance, 74, 79.

Komar, Mieke, Agoes, Etty R and Damian, Eddy (eds), (1999) Mochtar Kusumaatmadja: Pendidik dan Negarawan, Kumpulan Karya Tulis Menghormati 70 Tahun Prof. dr. Mochtar Kusumaatmadja, SH, LLM 568, 570.

League of Nations, Document C.351 (b), M.145 (b) (1930) v. 16, 189.

Ministry of Foreign affairs of the Republic of Indonesia, "On Indonesia's Archipelagic Sealanes" (Press Release No. 28/PR/VI/98, 15 June 1998) <www.deplu.go.id/english2/pr28-98.htm> at 27 March 2004.

Moore, John Norton, (1980), "The Regime of Straits and the Third United Nation Conference on the Law of the Sea" American Journal of International Law 74, 77, 121.

Natabaya, AS, (1978) “The Archipelagic Principles and Indonesia's Interests", Indonesian Quarterly 6 65, 66.

Priestnall, Graham, (1997) “The Regime of Archipelagic Sea Lanes Passage and Straits Transit Passage" Maritime Studies 96, 1, 4.

Reisman, Michael W, (1980), "The Regime of Straits and National Security: An Appraisal of International Law Making" American Journal of International Law 74, 48, 76.

Rothwell, Donald R and Bateman, Sam (eds), (2000), Navigational Rights and Freedoms and the New Law of the Sea, 144, 146.

Rothwell, Donald R and Bateman, Sam (eds), Navigational Rights and Freedoms and the New Law of the Sea 1, 6-7.

Van Dyke, J.M., Alexander, L.M., and Morgan, J.R. (eds) (1988) International Navigations: Rocks and Shoals Ahead?, 232.

Warner, Robin, (1997) "Defence Related Aspects of the Archipelagic Sea Lanes Regime" Proceeding of Annual Conference of Australia and New Zealand Society of International Law 5, 163, 168. 